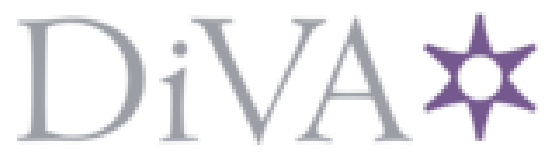

http://www.diva-portal.org

\title{
Postprint
}

This is the accepted version of a paper published in Small Enterprise Research: The Journal of SEAANZ. This paper has been peer-reviewed but does not include the final publisher proof-corrections or journal pagination.

Citation for the original published paper (version of record):

Schmidt, L., Gunnarsson, K., Dellve, L., Antonsson, A-B. (2016)

Utilizing occupational health services in small-scale enterprises: a 10-year perspective.

Small Enterprise Research: The Journal of SEAANZ, 23(2): 101-115

https://doi.org/10.1080/13215906.2016.1221358

Access to the published version may require subscription.

N.B. When citing this work, cite the original published paper.

Permanent link to this version:

http://urn.kb.se/resolve?urn=urn:nbn:se:kth:diva-198671 


\section{Utilizing occupational health services in small enterprises: A 10-year perspective}

\section{Lisa Schmidt}

IVL Swedish Environmental Research Institute, Box 21060, 10031 Stockholm, Sweden. Unit of Ergonomics, KTH Royal Institute of Technology, 14152 Huddinge, Sweden lisa.schmidt@ivl.se Tel: +46 (0) 107886528

\section{Kristina Gunnarsson}

Department of Occupational and Environmental Medicine, Uppsala University, 75185 Uppsala, Sweden. kristina.gunnarsson@ medsci.uu.se Tel: +46 (0) 18611 36 42/3.

\section{Lotta Dellve}

Unit of Ergonomics, KTH Royal Institute of Technology, 14152 Huddinge, Sweden. dellve@kth.se Tel: +46 (0) 87904895

\section{Ann-Beth Antonsson}

IVL Swedish Environmental Research Institute, Box 21060, 10031 Stockholm, Sweden. Unit of Ergonomics, KTH Royal Institute of Technology, 14152 Huddinge, Sweden. ann-beth.antonsson@ivl.se Tel: +46 (0) 107886547

${ }^{*}$ Corresponding author: Lisa Schmidt, IVL Swedish Environmental Research Institute, Box 21060, 100 31 Stockholm, Sweden. Tel: +46 (0) 1078865 28; Fax: +48859856400; E-mail: lisa.schmidt@ivl.se.

Acknowledgement: This work was supported by AFA Insurance and Forte: Swedish Research Council for Health, Working Life and Welfare.

\footnotetext{
ABSTRACT

The aim of this study was to explore how small-scale enterprises (SSEs) utilize occupational health services (OHS) and how the possibility of OHS providers to support occupational health and safety management has developed over a 10-year period. Qualitative interviews were carried out with four OHS providers and their small-scale enterprise clients, with follow-up interviews being conducted with three of the four OHS providers and their small enterprise clients after 10 years, all of whom had experienced a marked change over the 10-year period. The decade saw a change in market conditions for the three interviewed OHS providers with each becoming larger and developing more effective marketing tools. Despite these changes, the OHS providers had not developed more collaborative or closer relationships with their small enterprise clients. Rather than increasing, the utilization of OHS had declined, with health examinations remaining the most purchased service. In addition, the three OHS providers had improved their support for occupational health and safety management in small enterprises.
} 
Keywords: occupational health and safety management; occupational health services; small-scale enterprises; utilization of services; work environment

\section{Introduction}

More than 1.3 million people in Sweden, about 32\% of the workforce, work in privately owned small scale enterprises (SSEs) (Statistics Sweden, 2014). SSEs with fewer than 50 employees constitute more than $98 \%$ of all privately owned businesses, operate in most trades (Gunnarsson, Vingård, \& Josephsson, 2007) and contribute significantly to wealth and employment (Heyman, Norbäck, \& Persson, 2013).

In Sweden, Systematic Work Environment Management (Swedish Work Environment Authority, 2010) regulations require all enterprises to examine their equipment, organisation and procedures in order to ensure safe work routines and working environments. To achieve this, it is necessary to have knowledge of occupational health and safety (Frick, Eriksson, \& Westerholm, 2005). However, SSEs in general have difficulties in fulfilling their duties and obligations (Hasle, 2000; Lamm, 1997; Legg, Laird, Olsen, \& Hasle, 2014). Managements have a tendency to overestimate their knowledge (Kvorning, Hasle \& Christensen, 2015) and have little awareness of legislative requirements (Vickers, James, Smallbone \& Baldock, 2005; Baldock, James, Smallbone, \& Vickers, 2006). SSEs are inclined to believe that health and safety management is bureaucratic, legalistic and costly to introduce (Bibbings, 1995, Tait \& Walker, 2000). The problem of SSEs' poor safety performance and inability to respond to regulation has been highlighted previously (Kitching, 2006; Barrett, Mayson \& Bahn, 2014). It is important to influence SSEs to see the benefits of working with occupational health and safety. To what extent this can be achieved is dependent on personal contacts - e.g. with suppliers for information (Legg et al., 2010). One example of this is the creation of ENWHP (European Network for Workplace Health Promotion, 2001) by the EU, part of whose remit is to encourage SSEs to adopt good practice in workplace health promotion.

In situations where an employer is unable to fulfil his or her obligations with regard to Occupational Health and Safety Management (OHSM), the employer is required to use external resources, e.g. an Occupational Health Services (OHS) provider. The role of an OHS provider is defined as advisory, and the regulations specifically emphasise the Swedish OHS provider's role as an impartial expert (Swedish Work Environment Authority, 2010). However, official Swedish reports have indicated that OHS providers have difficulty reaching SSEs and that the individual healthcare aspect of the services from the OHS providers has been too extensive (Government Official Report SOU 2004:113). Research has also shown that it is difficult to reach SSEs with preventive measures (Champoux \& Brun, 2003; Hasle \& Limborg, 2006; Walters, 2001). Important tools to improve health and safety in SSEs are personal support, supplemented by guidelines and local networking (Andersson et al. 2004, Lehtinen, 2006). Even so, Swedish authorities have the expressed ambition of increasing access to 
OHS providers for SSEs in support of OHSM (The Public Health Agency of Sweden, 2011). In light of previous research indicating that SSEs need support, this article explores the role that OHS providers might play in that work.

The aim of this study was to explore how SSEs utilize OHS and to elicit the views of OHS providers on their possibility to support SSEs, as well as their interest in doing so, and how this has developed over a 10-year period. The results are intended to inform policymakers, regulators and stakeholders involved in the future development of the work environment at all levels of society. The results address the issue of occupational health and safety in SSEs in no specific context and raises questions that are also relevant to countries outside Sweden and Europe.

\section{Literature on SSES}

The sum of current knowledge on occupational health and safety in SSEs indicates that the focus of research has shifted from identifying the hazards to developing intervention strategies that can help create healthy workplaces (Legg et al., 2014). Although regarded as a heterogeneous group, SSEs do exhibit some common features - for example, their focus on the timely manufacture and delivery of products and services, and the low priority placed on the working environment (Walters, 2001; Laird, Olsen, Harris \& Legg, 2011). However, in comparison with large companies, the working environment in SSEs is associated with higher levels of risk, with greater exposure to physical and chemical hazards (Gunnarsson et al., 2007; Hasle \& Limborg, 2006; Sörensen, Hasle \& Bach, 2007; Legg et al., 2014) and difficulties in living up to occupational health and safety regulations and laws (Lamm, 1997; Baldock et al, 2006). Even so, on average SSEs have lower absentee levels than large firms, their employees are more motivated and the relationships between managers and employees is closer (de Kok, 2005). These firms often tend to be owner-managed, with dominant figures who handle all management issues based on personal beliefs and cultural values, rather than on stated directives (MacEachen et al., 2010). Many of the difficulties inherent in OHS management in SSEs can be explained by the wide-ranging responsibilities of managers for almost all activities, the focus on maintaining production being a necessity to ensure the company's survival, with little time remaining to deal with health and safety issues (Hasle, Bager, \& Granerud, 2010). It is obvious that management attitudes and the working conditions they foster have an impact on the culture of the organization. Additionally, an antipathy toward government intervention may adversely affect health and safety management (Baldock et al, 2006). Research has indicated that the approach of managers in SSEs to the working environment is governed not only by a lack of knowledge, but also by the priority placed on protecting themselves from personal responsibility and maintaining the social status quo within the company (Hasle, Kines, \& Andersen, 2009). Even if many managers have a strong sense of responsibility, they also give employees a high degree of autonomy and delegate significant areas of 
responsibility. For an individual employee it may be difficult to identify and understand the possible consequences of potential hazards (Holmes, Lingard, Yesilyurt \& De Munk, 1999). Safety is generally not a topic for discussion and the employees need to find ad hoc solutions to their problems (Ozmec, Karlsen, Kines, Andersen, \& Nielsen, 2015). Therefore, to a large extent responsibility for health and safety rests with the individual employee (Baldock et al., 2006) and accidents are often written off as the employee's own fault (Hasle, Limborg, Kallehave, Klitgaard, \& Rye Andersen, 2012).

SSEs have varying views and levels of awareness regarding regulations and inspections, which of course also influences their OHS performance (Vickers et al. 2005). Often they have no idea where to find information about or solutions to problems in the work environment and are suspicious of external consultants (Hasle \& Limborg, 2006). Many researchers have identified that SSEs often lack the knowledge, resources and ability to control their working environment (Antonsson, Birgersdotter, \& Bornberger-Dankvardt, 2002; Champoux \& Brun, 2003; Gunnarsson, Andersson, \& Rosén, 2010; Hasle \& Limborg, 2006). Personal support, supplemented by guidelines and local networking have been regarded as useful tools in supporting SSEs in improving health and safety (Andersson, Hägg, \& Rosén, 2006; Lehtinen, 2006). This support is dependent on personal contact, such as that from suppliers (Legg et al., 2010), creating a trusting relationship that can motivate their engagement (Hasle \& Limborg, 2006; Kvorning et al., 2015).

In summary, SSEs have a poor understanding of their responsibilities with regard to OHS regulations and legislation (Holmes et al, 1999). They suffer from a high risk of accidents and hazards in the workplace and a limited capacity to acquire the relevant knowledge. An understanding of how to identify risks is of course important but managers often lack the motivation to take the necessary steps to improve the working environment. Instead, they rely on their own interpretation of the risks and take action as and when they see fit (Hasle et al., 2012). Their expectations regarding the benefits of any collaboration with an OHS provider are limited as, for most SSEs, accidents are few and far between and they have an inbuilt suspicion of external consultants. Obviously, SSEs are in particular need of increased awareness, not only of their own responsibilities for preventive occupational health and safety measures, but also for providing support via their OHSM. A need for new strategies designed to reach and support them has been identified (Legg et al., 2014).

\section{Literature on OHS providers}

Internationally, systematic occupational health and safety management (OHSM) is seen as the main strategy to improve health and safety in the workplace. In Sweden, OHSM is regulated and mandatory (Swedish Work Environment Authority, 2010). OHSM processes are applicable to all types of businesses and are intended to be managed based on a collaborative dialogue and the participation of employees and safety representatives. According to Swedish regulations, employers are expected to arrange an OHS provider based on the requirements imposed by their working conditions. OHS providers are defined in the regulatory framework as an "independent expert resources" and their aim 
is "to reduce health risks and identify problems between the work environment, the organization, productivity and health". They should supply multidisciplinary services oriented toward preventing work-related diseases, promoting a healthy and safe working environment and sustaining and improving the ability of employees to work. Therefore, OHS providers should have expertise in behavioural science, preventive medicine, ergonomics, rehabilitation and technical safety, in order to offer comprehensive services covering the psychological, medical, technical and social aspects of work and the working environment (Swedish Work Environment Authority, 2010, 2013).

In 1991, the loss of funding subsidies to OHS providers led to a change in their ownership structure, resulting in the emergence of new market conditions. This change has contributed to the closure of a significant number of smaller independent OHS providers who were unable to cope with the difficult economic conditions (Bohlin, Hjalmarson, \& Westerholm, 2007). The role of the OHS provider has developed in the direction of a more market-oriented, client-focused business, in which OHS providers have strengthened ties with their clients' management (Frick et al., 2005).

Even if society is broadly supportive of the work of OHS providers, questions about their effectiveness and impact has been raised and discussed. Numerous governmental reports regarding their role, purpose and development have been produced (SOU; 2002, 2004, 2007, 2011a, 2011b; The Swedish Agency for Public Management, 2001a). Official reports have indicated that OHS providers have found it difficult to reach SSEs and that the healthcare services they provide have greatly outweighed their preventive services (SOU, 2004).

\section{Research questions}

Research has shown that there is a need to support SSEs in their OHSM; therefore, the following important questions need to be addressed: Has the scope of OHS providers' support to small business OHSM and preventive health and safety increased during the past decade? Has the business relationship between OHS providers and SSEs changed? Has the regulated role of OHS providers as an impartial OHSM expert changed?

\section{Materials and methods}

A qualitative method was deemed the most suitable approach for this type of study; using this method, researchers seek to explain, describe, explore or interpret the meaning of a phenomenon. The data collection method consisted of interviews intended to shed light on the interviewees' motives, attitudes, experiences and feelings in relation to the topic in question (Flyvbjerg, 2006; Kvale, 1997).

\section{Study 1}

A sample of four OHS providers was identified and selected to reflect OHS providers that have SSEs as clients and that vary in ownership, size and geographical location. All four OHS providers designated A-D, were independent OHS providers operating in a specific geographical region. A 
selection of the OHS providers' SSE clients was also selected to study their experiences of the services provided. An initial introductory phone call was made to the chief executive of each of the four OHS providers to explain the background to the study, all of whom were accessible and willing to participate. They were also asked to suggest a number of their SSE clients for the study. The selection criteria for the sample of SSEs were that they had less than 50 employees and represented a variety of industries and a diversity of experiences. In the interests of balance, they were informed of the need to avoid recommending only satisfied clients and to include both clients purchasing only basic services and those availing themselves of a wider range of products. The chief executive of each OHS provider then approached the five selected SSEs to request their participation. All four OHS providers were able to offer five SSE clients for the study; however, one of these was forced to cancel the interview at short notice. As a complement, telephone interviews were carried out with a number of other SSEs from the client lists provided by the OHS providers. The selected SSEs represented a variety of industries and trades; the timber industry, mechanical workshops, painting and decorating, vehicle services, accounting, hardware retailing, haulage, banking services and a fishmonger.

Semi-structured interviews were chosen as the method of investigation so that a degree of uniformity could be applied to the interview, while at the same time a sufficiently flexible approach could be maintained to allow respondents to make a contribution. Interview guides were developed for the various categories of interviewee and these guides related to a theoretical framework of previous research and official reports on OHS (Birgersdotter, Schmidt, \& Antonsson, 2002; BornbergerDankvardt et al., 2003; Bostedt, 1998; SOU, 2002; International Labour Organization, 1985; The Swedish Agency for Public Management, 2001b; Wissing et al., 2001). The interview guides covered a variety of topics focusing on the OHS providers' business strategies, types of agreement, procurement processes, business relationships, experience, obstacles, services and vision for the future when dealing with SSE clients. The same topics were addressed in the interviews with SSEs, with the interview guides containing questions about their OHSM work, their attitudes toward, knowledge of, experiences with and opinions on their individual OHS providers. Those interviewed from OHS providers were managers, OHS nurses, safety engineers, psychologists and a physiotherapist, with interviews being conducted at their respective offices. The interviews with SSE clients were conducted with managers, safety representatives and employees at their place of work. Telephone interviews covered matters relating to the interviewees' working environment and OHSM, their knowledge of their OHS provider as well as attitudes and experiences of the services obtained.

The visits and fieldwork were carried out by two researchers. Each interview lasted approximately one hour and left time for the respondents to include their experiences and opinions (Kvale, 1997). In total, 67 respondents were interviewed. 


\section{Study 2}

After 10 years the OHS providers were contacted and asked to participate in a follow-up study. Three of the four OHS providers agreed to participate. OHS A and C had been purchased by a larger OHS provider and incorporated into a wider geographic region. OHS B had been incorporated into a wider geographic region. OHS D declined to participate in the second round and findings from the first study relating to them have been disregarded.

For the second round of interviews recent research was studied (Frick et al., 2005; Gunnarsson et al., 2010; Hasle et al., 2010). The interview guides were shortened and adapted to be suitable for followup interviews by telephone. Due to limited financial resources, the interviews in the 2013 follow-up study were conducted by telephone with selected participants from the first round of interviews; managers at the OHS providers and managers at SSE clients.

The follow-up interviews were conducted at an agreed time and were carried out with managers at the OHS providers using the amended interview guide. The interviews ranged in length from 30-45 minutes and were recorded on audiotape with the interviewees' approval.

Attempts to contact the same SSEs interviewed in the first round were made, but these efforts proved futile. Several of the intended respondents had either gone out of business or had been taken over by a larger company. The OHS providers refused to approve any contact with their current SSE clients as becoming part of a larger OHS concern had led to a change of policy regarding contacting customers. Instead, website records were used to identify SSE clients of the selected OHS providers (allabolag.se n.d.). A total of 22 SSE clients were interviewed by telephone using adapted interview guide. Their businesses included vehicle services, accounting, haulage and mechanical workshops. Twenty-five respondents participated in the second round of interviews. Only one respondent was interviewed on both occasions. One researcher conducted interviews in both rounds of the study.

Insert table 1 here

\section{Data analysis}

The purpose of the analysis was to explore SSEs utilization of OHS, as well as OHS providers' possibility to support OHSM in SSEs. The data from the first round of interviews with OHS providers and SSEs in 2003 was noted in writing at each visit. This data was subjected to qualitative content analysis and was read through several times with coding categories defined based on the interview guides; organization of work and data on the OHS provider, market conditions, SSEs as a proportion of the total number of clients, awareness, attitudes and experiences of the relationship with SSE clients, utilization, services and support. In the analysis, shared attitudes and experiences were 
identified and were organized around utilization, communication and collaboration between the OHS providers and their SSE clients.

In the second round in 2013, follow-up telephone interviews with OHS providers were tape-recorded and then transcribed post interview, in contrast to the follow-up telephone interviews with SSEs, which were transcribed in note form during the interview. The transcribed texts were read through several times and content analysed, in order to obtain meaning and understanding about the communication, collaboration and utilization of services (Hsieh \& Shannon 2005; Miles \& Huberman, 1994).

The analysis was focused on the SSEs' utilization of services and support, and on both parties' experience of the relationship and collaboration. Finally, the two analyses were compared and the material organised into overarching themes relevant to the changes, or stability, in OHS market conditions, the OHS providers' marketing practices, and the interviewees' perceptions and mutual satisfaction over the course of the decade.

\section{Results}

\section{A changed market, but no significant change in services}

In the first round of interviews, the three OHS providers (A, B and C) were independent providers in different regions. A considerable proportion of their clients, approximately 70\%, were SSEs. The most commonly purchased service for SSE clients was health examinations. Occasionally, they purchased other OH services but seldom purchased preventive services or support for OHSM. In the second round of interviews, two of the OHS providers (A and C) had changed ownership and had been taken over by two larger providers. OHS B was still part of the same concern as at the time of the first interview but had carried out some internal reorganisation, resulting in the same number of employees operating from fewer offices. This merger into larger OHS providers had not increased the number of affiliated SSE clients, despite an increase in the total number of SSEs in the labour market over the previous 10 years. Instead, the proportion of SSEs had decreased to approximately $50 \%$ of the clients in the larger OHS organisations.

Insert Table 2 here

In the second round of interviews, the OHS respondents described the services provided to their SSE clients as much the same as at the time of the first interviews; the utilization and provision of services remained unchanged and health examinations were still the most purchased service. The OHS respondents did emphasise two small changes; an increase in the purchase of ergonomic assessment services and an upward trend in the provision of psychosocial services to SSE clients. 


\section{No change in how OHS providers market their services to SSES}

According to the first interviews in 2003, OHS providers were keen to increase their contact with SSEs; they emphasised the need to increase the scope of preventive work and to offer services addressing work environment issues. In the second interviews, OHS provider A described the actions taken to increase business with SSEs. The provider had become more aware of and inspired by the potential opportunities raised in the discussion during the first interview. In order to increase the number of SSE clients, a specialised SSE team was subsequently formed and action taken to establish improved contacts with potential SSE clients. As a result, the proportion of SSE clients had increased but unfortunately this teamwork had not continued after the merger into a new and larger OHS organisation.

The new market conditions had not noticeably changed any aspects of the OHS providers' business with SSEs. Larger OHS providers might be expected to lead to increased marketing budgets; however, the OHS respondents claimed that economic realities meant that they could not afford to market more aggressively to potential SSE clients. OHS C admitted that they had never marketed their services to SSE clients because they were assessed as having poor purchasing power. The other two OHS providers claimed that their marketing to potential SSE clients remained unchanged.

All of the OHS providers in the study had a marketing strategy of focusing on larger companies, often based on regular and personal contacts; for economic reasons they did not consider it feasible to have the same arrangement for SSE clients.

At the second interview, all OHS respondents again emphasised the importance of increasing their contacts with SSEs in order to increase their client base. Largely for financial reasons, they saw the need to spread their economic risk across both large and small clients. In order to achieve this, they needed to learn more about the conditions at SSEs and to create opportunities for closer relationships. Some of the OHS providers expressly stated that they had not succeeded in reaching SSE clients over the intervening years and that it was now becoming an important issue for them to persuade SSEs to utilized OHSM services. As the OHS A interviewee highlighted, "we must be useful; SSEs must experience that it is of great value to engage us".

During both rounds of interviews, an increase in the number of SSE clients was reported to be a significant business issue, but despite its stated importance, no such growth had occurred. On a national level, collaboration between SSEs and OHS providers has even decreased. Aside from the one, prematurely terminated, attempt by OHS provider A, none of the OHS providers had succeeded in galvanising a new approach to SSE clients.

The findings show that the new economic market with larger OHS organisations has not increased support for OHSM or improved the work environment for SSE clients of OHS providers. The changing circumstances for OHS providers have not lead to developments in the marketing of their 
services to SSEs, even if the providers see the potential benefits of expanding their client base. Nothing has changed in how services are marketed: contact is generally made on an annual basis, either by telephone or mail. The OHS providers have been unable to increase the number of SSE clients, despite their stated belief that such an increase is important to their business. Instead, the total share of clients had decreased during the decade (The Public Health Agency of Sweden, 2011). Despite the Government's stated ambition to increase the role of OHS providers in promoting and supporting preventative health and safety measures and OHSM in SSEs, their contribution is still negligible.

\section{OHS providers' views on and strategies for SSE clients}

The OHS respondents were unable to define in any detail what a more active role with SSE clients might entail or how it could be achieved. In the first round of interviews, the OHS providers described their relationships with SSE clients as different from those with larger clients. SSE client relationships were viewed more negatively as being time-consuming, costly and problematic. As customers, SSE managements were described as lacking in time and resources, being diverted by other concerns and failing to prioritise work environment issues. Significant time and resources were required to start a dialogue and communicate with SSE management in order to reach a common understanding or agreement. Therefore, SSE clients were not considered a priority.

The OHS providers also reported that developing any form of collaboration was a challenge, as SSE managers often have difficulty making time for an appointment with the OHS providers' representative. In addition, issues and problems are often discussed outside of the company's ordinary processes, frequently during a break in production. The OHS C interviewee explained: "SSEs are like a family; the owner has a double role and is often working in production".

In both rounds of interviews, OHS providers explained the lack of relationships and collaboration with SSEs as a result of their clients' limited resources. They indicated that SSE managers are not trained in OHSM and are less likely to seek assistance. It is apparent that SSE managements are often unaware of OHS regulations and, as noted previously, SSEs in general have limited knowledge of legislative requirements (Kitching, 2006; Barrett et al., 2006). The OHS providers emphasized that some of their SSE clients constantly operate in fire-fighting mode and lack the motivation to change their approach to managing the work environment. The OHS providers had not converted their business with SSE clients into deeper and more collaborative relationships.

\section{SSES' views on OHS providers}

According to the SSE respondents during the two rounds of interviews, their motivations or aims in purchasing OHS services mainly concerned the wellbeing and health of their employees. In a handful 
of cases, demands from customers or trade unions had been the reason behind their relationship with an OHS provider.

In the first round of interviews, the respondents expressed concern that their OHS provider did not act in their best interest. They viewed the OHS provider as seeking to create a problem or suggesting one specific solution, instead of attempting to find alternatives. This situation had created a suspicion that the OHS provider's main interest was to force the SSE to purchase a service.

In the second interview round, the SSEs were more aware of their status as client, which can be an effect of the change in the market for OHS services. The SSEs interviewed in 2013 were more likely to have changed their OHS provider during recent years than those interviewed in 2003, either because they were not satisfied with the performance and level of expertise or because the services supplied failed to live up to expectations. This finding might be interpreted as indicating that SSE respondents have increased their business awareness and are more inclined to evaluate the level of services delivered by their OHS provider.

None of the SSE respondents had requested or enquired about other services from their OHS provider; they seemed content with the relationship as it was. One SSE interviewee commented: "The OHS business is not exactly out there marketing their services. To provide some information without imposing unwanted and costly services can be a better way to increase interest in OHS services". Cost continued to be reported as a reason for not purchasing more services or for not purchasing OHS at all. Consequently, the main service purchased by SSEs remains health examinations, which although not required by law are seen as a benefit for employees. This finding confirms earlier studies showing that health examinations are the most commonly purchased of OHS providers' services, are in great demand by SSE employees and are considered as a benefit (Gunnarsson, Andersson, \& Josephsson, 2011). Research has shown that occasional health examinations alone neither reduce employee absenteeism nor increase work ability. If health examinations are followed up with proposals for improvements in the working environment and with follow-up examinations, they might improve health conditions. Health examinations are often valued as a motivational fringe benefit (Grooten et al., 2013; Grooten et al., 2014). It is interesting that to a large extent, the SSE interviewees associated their OHS provider with individual health and did not view them as a support for their internal OHSM. This finding also indicates that OHS providers have not succeeded in marketing their services and resources; and have not developed more of a consultative role as an impartial expert in OHSM.

\section{Mutual satisfaction with the relationship without doing what is required}

It is obvious that there is room for increased utilization of OHS providers' expertise and competencies in work environment tasks. However, even though regulatory requirements are not being fulfilled, both OHS providers and their SSE clients seemed satisfied with their alliance. The results indicate that OHS providers do not visit or have access to the workplace and have not increased their possibilities 
to support OHSM in SSEs. If they are serious in their intention to provide a wider range of services to support OHSM in the workplace, providers must create legitimacy among their current and potential SSE clients. These conditions had not changed during the decade under study, and neither the OHS providers nor their SSE clients showed any interest in such a change.

\section{Lack of development}

In fact, the use of OHS in SSEs has shown no significant change. In both rounds of interviews, most of the SSE clients reported they had some form of basic agreement for OHS services; however, several of the respondents knew little about the content of the agreement or any potential additional services. The service often involved little more than offering advice over the telephone and providing information on new regulations from the Swedish Work Environment Authority. OHS providers state with a note of resignation that many SSE clients only wish to purchase health examinations only. From the SSEs perspective, OHS services are traditionally seen as being for assistance with individual health problems, not for support in handling working environment issues. They were pleased with the OHS services provided and did not see any benefits in changing or extending the service. Even if they knew little about the effects of health examinations, they appreciated the service as provided. Obviously, with a significant part of the provided services focusing on health examinations, the interviewed OHS providers felt no motivation to help their SSE clients to understand, investigate or improve their working environment. As such, they are not fulfilling their regulated function as impartial OHSM experts.

\section{Discussion}

This paper presents a 10 year perspective of how SSEs utilize OHS services and the possibility of OHS providers to support SSEs. The results show no essential differences in the nature of relationships or services purchased during the period, although a decrease in the percentage of SSEs with OHS agreements was indicated. SSEs claimed they were aware of their OHS providers' range of services but considered them to be of limited use. They were also unable to identify any specific requirements and this finding regarding the inability of SSE respondents to identify any problems in their working environment is in line with the findings of other researchers (Antonsson et al., 2002; Gunnarsson et al., 2010; Hasle \& Limborg, 2006).

The present study can be summarised in terms of three major findings. The first of these concerns the evolution of the market into larger OHS providers. It is problematic when, under the terms of the Swedish Work Environment Act, an industry such as the OHS sector is expected to provide services and support, while the free market is assumed to manage supply and demand. The Act states what an OHS provider ought to be and offer in terms of support to a company's OHSM - unfortunately these services are not in demand to any great degree. It is not surprising then that SSEs lack the requisite 
knowledge or awareness of what OHSM requires (e.g. Baldock et al, 2006). They are not interested in utilizing services the value of which they do not understand. The second conclusion we can draw from this analysis, is that to a large extent the only service that is in demand is health examinations are requested. Often as a benefit for employees and from the OHS providers point of view, as an important source of income. Clearly, SSEs regard OHS suppliers as healthcare providers, managing health examinations and rehabilitation. A study of the web-sites and marketing materials of large OHS providers shows clearly that, in terms of activities in the workplace, these are mainly based on individual health issues and not on services and support for OHSM. The third and final finding is that the majority of both SSEs and OHS providers appear to be content and generally satisfied with their collaboration and how services are utilized. The study indicates that there is no interest in improving the situation and, taken together, the findings show no indications of change. If the goal of the Swedish authorities is truly to increase OHSM in SSEs with support from OHS providers, they need to push for a different approach. In order to develop a more collaborative relationship regarding OHSM, OHS professionals need to understand the business models and working environments within SSEs. The SSEs themselves also need to improve their knowledge of regulations and legislation. There seems to be no short-term solution to this problem. One appropriate strategy would be to provide the resources needed to substantially increase the number of health and safety inspections undertaken (Baldock et al, 2006). This is difficult as the Swedish Work Environment Authority has been slimmed down, with the number of health and safety inspectors in particular having decreased during the decade until it fell below the ILO recommended level. Today, the number of health and safety inspectors is increasing but this does not provide a long-term solution. A previous attempt to provide Government financing to OHS providers to support rehabilitation initiatives was far from successful. Financial inducement from the Government is often a complex administrative process making it difficult for SSEs to obtain grants.

It appears that a change of course is required, possibly involving other types of services or even suppliers. In order to support OHSM in SSEs, OHS providers must build closer relationships with their SSE clients and it is significant that a successful relationship is built on trust and confidence (Schmidt et al., 2014). The role of interpersonal relationships in the purchasing of OHS and the value of communication skills have been well-demonstrated (Lian \& Laing, 2007). OHS providers also need to develop and introduce new methods and tools (Launis \& Gerlander, 2005). Research has also indicated that development of flexible, tailor-made services is needed. However, in the free market professionals have limited opportunities due to the cost in time and resources of stimulating dialogue with clients and where "some efforts will not pay off" (Sieg, Fischer, Wallin, \& von Krogh, 2012). It is possible that some form of financial subsidy to OHS providers for supporting OHSM within SSEs could be successful. 


\section{Methodological considerations}

There is a challenge with longitudinal approaches, since conditions are continually changing. A limitation of this research is that only three of the four OHS providers were interviewed in the followup round of interviews. Thus, the paper can be viewed as two snap-shots 10 years apart. However, the results provide a 10 year perspective as the interviewees also were asked to reflect retrospectively about the 10 last years.

A possible problem could emerge if the OHS providers were to only propose clients with favourable opinions and this is why in the first round of interviews we specifically requested not only satisfied clients. This was not a problem in the second round were several contextual factors had changed and the OHS provider did not provide any customer contacts. A challenge in the second round was to make contact with the SSEs as clients. We had to identify them ourselves and it proved difficult to find SSE clients for the second interview, simply because some of them had gone out of business and others had evolved into larger enterprises that were no longer suitable for the purposes of our study. Still, we succeeded in getting in touch with them. Despite these limitations, the results illustrate the complexity of the relationships between OHS providers and their SSE clients and may increase understanding of the opportunity of OHS providers to support SSE clients in their OHSM.

\section{Conclusions}

Our study demonstrates that the status quo has been maintained in the relationships between SSE clients and their OHS providers during the decade under investigation. Despite the change in market conditions with many small OHS providers merging into larger companies, no associated development in service utilization, collaboration or support has occurred. Being part of a larger company could have served as an opportunity to improve marketing aimed at SSEs. However, despite societal changes and the developments towards the regulation of procedures, OHS providers still seem to focus on services related to individuals and individual health in particular. The interviews reveal that marketing strategies aimed at SSEs had not changed.

This study has shown that the opportunity of OHS providers to support SSEs, or indeed to be the impartial OHSM expert as envisioned in the current legislation, whether due to lack of marketing or a lack of interest on the part of SSEs, has not increased during the decade. As a previous study pointed out, it takes two to tango and in the case of SSE clients, neither of the prospective partners seems inclined to take to the dance floor (Schmidt et al. 2015). The current work helps to further our understanding of the relationship between SSEs and OHS providers. No change can be expected, nor is there any driving force pushing for change; therefore, long-term, concerted efforts are required to change entrenched views on the collaboration between OHS providers and SSEs. According to the findings, changing how SSEs use the services available form OHS providers', and particularly their 
use of services related to prevention and OHSM, will require serious consideration by the Swedish government in order to create the necessary conditions to support another form of collaboration.

\section{Acknowledgements}

The project was funded by a grant from AFA Insurance and Forte: Swedish Research Council for Health, Working Life and Welfare. The study was undertaken within the IVL Swedish Environmental

Research Institute. We would also like to thank the participating OHS providers and SSEs for being so generous in sharing their experiences and points of view during the two rounds of interviews. 


\section{References}

Allabolag. [All companies]. Retrieved from http://www.allabolag.se/om

Andersson, I.-M., Christmansson, M. Hägg, G., Karlqvist, L. \& Rosén, G. (2004). Strategier för arbetsmiljöarbete i svenska organisationer in I.-M. Andersson, G.M. Hägg, \& G. Rosén, (eds.), Arbetsmiljöarbete i Sverige (2004): En kunskapssammanställning över strategier, metoder och arbetssätt för arbetsmiljöarbete. [Work environment management in Sweden (2004)]: A knowledge compilation of strategies, methods and procedures for work environment]. Arbete och hälsa [Work \& Health], 6, 13-23. Stockholm, Sweden: Arbetslivsinstitutet - National Institute for Working Life.

Antonsson, A.-B., Birgersdotter, L., \& Bornberger-Dankvardt, S. (2002). Small enterprises in Sweden: Health and safety and the significance of intermediaries in preventive health and safety. (Report, No. 2001:1) Stockholm, Sweden: Arbetslivsinstitutet - National Institute for Working Life.

Swedish Work Environment Authority. (2010). Systematiskt Arbetsmiljöarbete [Systematic work environment management]. Regulations 2001:1. Stockholm, Sweden: Arbetsmiljöverket - Swedish Work Environment Authority.

Swedish Work Environment Authority. (2013). Work Environment Act 1977:1160. Retrieved from https://www.av.se/arbetsmiljoarbete-och-inspektioner/lagar-och-regler-omarbetsmiljo/arbetsmiljolagen/

Baldock, R., James, P., Smallbone, D., \& Vickers, I. (2006) Influences on small-firm compliancerelated behaviour: the case of workplace health and safety. Environment and Planning $C-$ Government and Policy, 24(6), 827-846.

Barrett, R., Mayson, S., Bahn, S. (2014) Small firms and health and safety harmonisation: Potential regulatory effects of a dominant narrative. Journal of Industrial Relations. Vol. 56(1), 62-80.

Bibbings, R. (2003). Strategy for meeting the occupational safety and health needs of small and medium size enterprises (SMEs) - A summary of ROSPA's views. Safety Science Monitor, 7(1), 113.

Birgersdotter, L., Schmidt, L., \& Antonsson, A.-B. (2002). Fungerande systematiskt arbetsmiljöarbete i små företag - Erfarenheter från 45 små arbetsställen. [Experiences from 45 small companies with good systematic work environment management]. IVL-rapport B 1475, Stockholm., Sweden.

Bohlin L., Hjalmarson L., \& Westerholm P. (2007). Occupational health services in Sweden. Policy and Practice in Health and Safety, 5, Suppl. 1(13), 111-123.

Bornberger-Dankvardt, S., Ohlson, C-G., Westerholm, P. (2003). Arbetsmiljö- och hälsoarbete i småföretag - försök till helhetsbild. [Work environment and health promotion in small-scale enterprises]. Arbetsliv i omvandling 2003:1, (Work Life in Transition, National Institute for Working Life). Stockholm, Sweden: Arbetslivsinstitutet - National Institute for Working Life.

Bostedt, G. (1998). Strategier för arbetsmiljöarbete. En studie av medelstora privata företags arbetsmiljöarbete och perspektiv på företagshälsovård. [Strategies for work environment. A study of medium-sized private companies' work environment and perspectives on occupational healthcare]. Mid Sweden University, Institutionen för företags- och förvaltningsutveckling, Sundsvall, Sweden. 
Champoux, D., Brun, J. (2003). Occupational health and safety management in small size enterprises: An overview of the situation and avenues for intervention and research. Safety Science, 41(4): 301318.

de Kok, J.M.P. (2005). Precautionary Actions within Small and Medium-Sized Enterprises. Journal of Small Business Management 2005, 43(4) pp.498-516.

European Network for Workplace Health Promotion, 2001. Available at http://www.enwhp.org/

Flyvbjerg, B. (2006). Five Misunderstandings About Case-Study Research Qualitative Inquiry, Vol 12, No 2, 219-245.

Frick K., Eriksson O., Westerholm P. (2005). Work environment policy and the actors involved. In R.Å. Gustavsson \& I. Lundberg, (Ed.), Worklife and health in Sweden 2004 (pp 417 \& 428). National Institute for Working Life, Stockholm, Sweden.

Grooten, W., Äng, B., Müller, M., Toomingas, A., Kjellberg, K., Forsman, M., Stoetzer, U., Svartengren, M., Åborg, C. (2013). Företagshälsovårdens arbete med hälsoundersökningar. [Occupational health services' work with medical examinations]. Karolinska Institutet, NVS-sektionen för sjukgymnastik, Stockholm, Sweden.

Grooten W., Kader M., Bergström G., Hermansson U., Kwak L., Schäfer Elinder L., Wåhlin C., Jensen I. (2014). Effekter av hälso- och levnadsvaneundersökningar. Vad säger den vetenskapliga evidensen? [Effects of health and living habit studies. What does the scientific evidence show?]. Rapport. Karolinska Institutet, Stockholm, Sweden.

Gunnarsson, K., Andersson, I-M., Josephsson, M. (2011). Swedish entrepreneur's use of occupational health services. AAOHN, Oct; 59 (10): 437-45.

Gunnarsson, K., Andersson, I-M., Rosén, G. (2010). Systematic Work Environment Management: Experiences from Implementation in Swedish small-scale enterprises. Industrial Health, 48, 185-196.

Gunnarsson, K., Vingård, E., Josephsson, M. (2007). Self-Rated Health and Working Conditions of small-scale enterprises in Sweden. Industrial Health, 45, 775-780.

Hasle, P. (2000). Health and safety in small enterprises in Denmark and the role of intermediaries. Center for Alternativ Samfundsanalyse, Copenhagen.

Hasle, P., Bager, B., Granerud, L. (2010). Small enterprises - Accountants as occupational health and safety intermediaries. Safety Science, 48, 404-409.

Hasle, P., Kines, P., Andersen, LP. (2009). Small enterprise owner's accident causation attribution and prevention. Safety Science, 47, 9-19.

Hasle, P., \& Limborg, H.J. (2006). A review of the literature on preventive occupational health and safety activities in small enterprises. Industrial health, 44(1): 6-12.

Hasle, P., Limborg, J., Kallehave, T., Klitgaard, C., Rye Andersen, T. (2012). The working environment in small firms: Responses from owner-managers. International Small Business Journal, 30(6) 622-639. 
Heyman, F., Norbäck, P-J., Persson, L. (2013). Var skapas jobben? En ESO-rapport om dynamiken $i$ svenskt näringsliv 1990 till 2009. [Where are jobs created? An ESO report about the dynamics of Swedish Enterprise 1990-2009]. ESO-rapport 2013:3, Expert Group for Studies in Public Finance, Stockholm, Sweden: Finance Department, Government Offices of Sweden.

Holmes, N., Lingard, H., Yesilyurt, Z., De Munk, F. (1999) An exploratory study of meanings of risk control for long term and acute effect occupational health and safety risks in small business construction firms. Journal of Safety Research, Vol. 30, No.4, 251-261.

Hsieh H-F., \& Shannon, S. (2005). Three Approaches to Qualitative Content Analysis Qualitative Health Research, 15: 1277.

International Labour Organization. (1985). Convention Concerning Occupational Health Services, Convention: C 161, 1985.

Kitching, J. (2006), A burden on business? Reviewing the evidence base on regulation and smallbusiness performance. Environment and Planning C: Government and Policy, vol. 24, 799-814.

Kvale, S. (1997). Den kvalitativa forskningsintervjun. [Qualitative Research Interviews]. (In Swedish). Lund, Sweden: Studentlitteratur.

Kvorning, L. V., Hasle, P., \& Christensen, U. (2015). Motivational factors influencing small construction and auto repair enterprises to participate in occupational health and safety programmes. Safety Science, Special Issue, 71, 253-263.

Laird, I., Olsen, K., Harris, L-A., Legg, S., (2011). Utilising the characteristics of SMEs to assist in managing hazardous substances in the workplace. International Journal of Workplace Health Management, Vol 4 No 2, 140-163.

Lamm, F. (1997). Small businesses and OH \& S advisors. Safety Science, 25 (1-3): 153-161.

Launis, K., Gerlander E.M. (2005). Work life changes challenge the object formation of occupational health services. Scandinavian Journal of Work, Environment \& Health. Suppl 1[19-22].

Legg, S., Laird, I., Olsen, K., Hasle, P. (2014). Guest Editorial: Special Issue - Understanding small enterprises: Healthy lives in healthy business. Small Enterprises Research, 21:2, 139-147.

Legg, S., Olsen, K., Lamm, F., Laird, I., Harris, L-A., Hasle, P. (2010). Understanding the programme theories underlying national strategies to improve the working environment in small businesses. Policy and Practice in Health and Safety, Issue 2, pp 5-35 (31).

Lehtinen, S. (2006). Activities and Ways of Organizing Better Occupational Health and Safety in Small Workplaces: Special Focus on Information. Industrial Health, 44, 13-16 (2006).

Lian, P.C.S., \& Laing, A.W. (2007). Relationships in the purchasing of business to business professional services: The role of personal relationships. Industrial Marketing Management, 36, 709718.

MacEachen, E., Kosny, A., Scott-Dixon, K., Facey, M., Chambers, L., Breslin, C., Kyle, N., Irvin, E., Mahood, Q., Bigelow, P., Morassaei, S., Couban, R., Shannon, H., Cullen, K., Amick III, B.C. (2010). Workplace Health Understandings and Processes in Small Businesses: A Systematic Review of the Qualitative Literature. J Occup Rehabil, (2010) 20: 180-198. 
Miles, M.B., \& Huberman A.M. (1994). Qualitative data analysis: An expanded sourcebook. Thousand Oaks, California: Sage Publications, 1994.

Ozmec, M.N., Karlsen, I.L., Kines, P., Andersen, L.P.S, Nielsen, K.J., (2015). Negotiating safety practice in small construction companies. Safety Science 71, pp. 275-281.

Schmidt, L., Sjöström, J., Antonsson, A-B. (2014). Successful collaboration between occupational health service providers and client companies: key factors. Work 51 (2015) 229-237.

Sieg, J.H., Fischer, A., Wallin, M.W., von Krogh, G. (2012). Proactive diagnosis: how professional service firms sustain client dialogue. Journal of Service Management, Vol. 23 No.2, pp 253-278.

SOU. (2002) Handlingsplan för ökad hälsa i arbetslivet. [Action plan to improve health in the workplace]. (Report No. 2002:5). Stockholm, Sweden: Ministry of Health and Social Affairs.

SOU. (2004). Utveckling av god företagshälsovård - ny lagstiftning och andra åtgärder.

[Development of good occupational health services - new legislation and other measures]. (Report No. 2004:113) Stockholm, Sweden: Ministry of Employment.

SOU. (2007) Ny företagshälsovård - ny kunskapsförsörjning [New occupational health services - new knowledge supply]. (Report No. 2007:91). Stockholm: Fritzes.

SOU. (2011a) Framgångsrik företagshälsovård - möjligheter och metoder. [Successful occupational health services - possibilities and methods]. (Report No. 2011:63). Stockholm: Fritzes.

SOU. (2011b). Kunskapsområdet företagshälsovård - en rapport om utbildning, utveckling och forskning. [The field of knowledge occupational health services - a report on training, development and research]. (Report No. 2011:79) Stockholm: Fritzes.

Statistics Sweden, SCB. Företagsdatabasen [Labour Force Survey]. Retrieved 160221 from http://www.scb.se/sv_/Hittastatistik/Statistikdatabasen/Variabelvaljare/?px tableid=ssd extern\%3aFDBR07\&rxid=6bfbb9cfa76b-4eef-8a49-e8e46721f988

The Swedish Agency for Public Management. (2001a). Utnyttja företagshälsovården bättre! [Better use of Occupational Health Services.] (Report No. 2001:29). Stockholm, Sweden: The Swedish Agency for Public Management.

The Swedish Agency for Public Management. (2001b). Långsiktig verksamhetsutveckling ur ett arbetsmiljöperspektiv. En handlingsplan för att förnya arbetsmiljöarbetet. Ds 2001:28. [Long-term business development from a work perspective. An action plan to renew the work environment]. Stockholm, Sweden: The Swedish Agency for Public Management.

Swedish Institute of Public Health. (2011). Målområde 4. Hälsa i arbetslivet. [Objective 4. Health and safety at work]. Kunskapsunderlag för Folkhälsopolitisk rapport 2010. Östersund, Sweden: Swedish Institute of Public Health,

Sörensen, O.H., Hasle, P., Bach, E. (2007) Working in SMEs - Is there a special risk? Safety Science, 45, 1044-1059.

Tait, R., \& Walker, D. (2000). Marketing health and safety management expertise to small enterprises. Safety Science, 26, 95-110. 
Vickers, I., James, P., Smallbone, D., Baldock, R. (2005). Understanding small firm response to regulation: The Case of Workplace Health and Safety. Policy Studies, Vol. 26, No 2,

Walters, D. (2001). Health and Safety in small Enterprises. European Strategies for Managing Improvement. Brussels: P.I.E. - Peter Lang.

Wissing, P., Hasle, P., Grinderslev, E., Frandsen, O., Andersen, M., Bager, B., Porse, G., Wibroe, L. (2001). God BST-service til små virksomheder - rapport fra et fors $\emptyset g$ sprojekt i BST Frederiksborg. [Good BST-service to small businesses - report from a pilot project in BST Frederiksborg] Casaanalyse, Denmark. 
Table 1 Respondents in OHS providers and SSEs in 2003 and 2013

\begin{tabular}{|c|c|c|}
\hline \multicolumn{3}{|c|}{ Respondents interviewed in 2003} \\
\hline OHS A & \multicolumn{2}{|c|}{ Manager, OHS nurse, safety engineer, psychologist } \\
\hline 4 SSES & Visited and interviewed & Managers and safety representatives \\
\hline 4 SSES & Interviewed by phone & Managers \\
\hline OHS B & \multicolumn{2}{|c|}{ Manager, OHS nurse, safety engineer, psychologist } \\
\hline 5 SSES & Visited and interviewed & Managers and safety representatives \\
\hline 5 SSES & Interviewed by phone & Managers \\
\hline \multicolumn{3}{|c|}{\begin{tabular}{|l|l|}
\multicolumn{2}{|l}{} \\
OHS C & Manager, OHS nurse, safety engineer, psychologist \\
\end{tabular}} \\
\hline 5 SSES & Visited and interviewed & Managers and safety representatives \\
\hline 5 SSES & Interviewed by phone & Managers \\
\hline OHS D & \multicolumn{2}{|c|}{ Manager, OHS nurse, safety engineer } \\
\hline 5 SSES & Visited and interviewed & Managers and safety representatives \\
\hline 5 SSES & Interviewed by phone & Managers \\
\hline \multicolumn{3}{|c|}{ Respondents interviewed by phone in 2013} \\
\hline OHSA & Manager & Managers in 4 SSE clients \\
\hline OHS B & Manager & Managers in 4 SSE clients \\
\hline OHSC & Manager & Managers in 4 SSE clients \\
\hline
\end{tabular}


Table 2 Changes in characteristic and client profile for the three OHS providers

\begin{tabular}{|c|c|c|c|c|c|}
\hline OHS & Year & Characteristic & $\begin{array}{l}\text { Total number of } \\
\text { client companies }\end{array}$ & $\begin{array}{l}\text { Number } \\
\text { of SSEs }\end{array}$ & $\begin{array}{l}\text { Proportion of } \\
\text { SSEs of all } \\
\text { customers }\end{array}$ \\
\hline \multirow{2}{*}{$A$} & 2003 & $\begin{array}{l}\text { A small independent OHS in a } \\
\text { smaller geographic region }\end{array}$ & 190 & 120 & $63 \%$ \\
\hline & 2013 & $\begin{array}{l}\text { Purchased by a larger OHS } \\
\text { provider and incorporated into a } \\
\text { larger geographic region }\end{array}$ & 220 & 120 & $54 \%$ \\
\hline \multirow{2}{*}{ B } & 2003 & $\begin{array}{c}\text { An independent } \mathrm{OHS} \text { in a smaller } \\
\text { geographic region }\end{array}$ & 220 & 140 & $64 \%$ \\
\hline & 2013 & $\begin{array}{l}\text { Incorporated into a larger } \\
\text { geographic region }\end{array}$ & 254 & 108 & $41 \%$ \\
\hline & 2003 & $\begin{array}{l}\text { A small independent } \mathrm{OHS} \text { in a } \\
\text { smaller geographic region }\end{array}$ & 180 & 140 & $77 \%$ \\
\hline & 2013 & $\begin{array}{l}\text { Purchased by a larger OHS } \\
\text { provider and incorporated into a } \\
\text { larger geographic region }\end{array}$ & 142 & 72 & $50 \%$ \\
\hline
\end{tabular}

